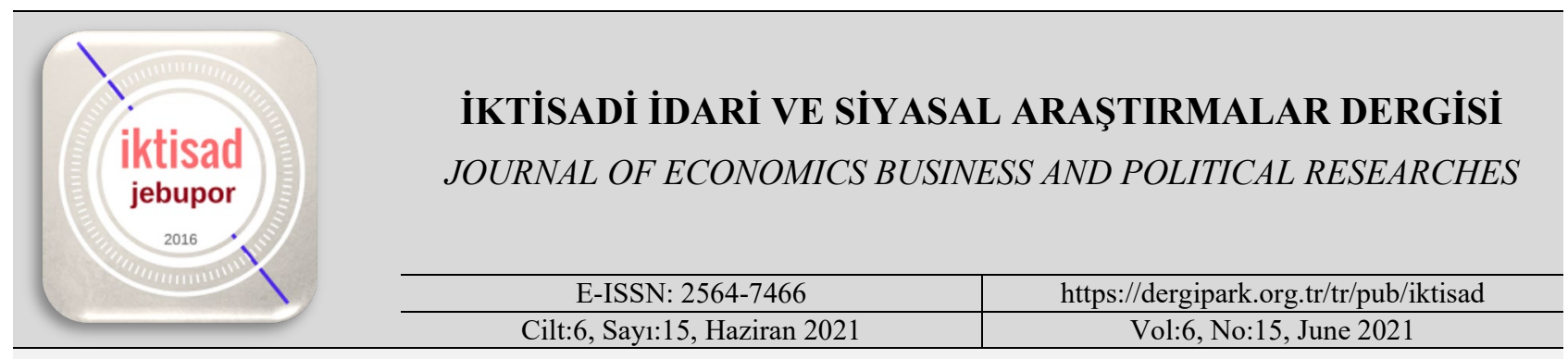

\title{
COVID-19 Treatment Costs in Turkey: Determinants and Burden of the Social Security Institution \\ ↔.
}

\author{
Türkiye’de COVID-19 Tedavi Maliyetleri: Sosyal Güvenlik Kurumuna Yükü \\ ve Belirleyicileri
}

Makale Bilgileri

Makale Türü:

Araştırma Makalesi

Geliş Tarihi:

21.12.2020

Kabul Tarihi: 07.04.2021

(C) 2021 IKTISAD Tüm hakları saklıdır.

\section{$\underline{\text { Article Info }}$}

Paper Type:

Research Paper

Received:

21.12.2020

Accepted:

07.04.2021

(C) 2021 JEBUPOR All rights reserved.

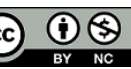

\begin{abstract}
This study aims to investigate the burden of treatment costs of patients hospitalized with COVID19 on the Social Security Institution (SSI) and determinants of COVID-19 treatment costs. This research is a retrospective study. The study examined 389 patient files that were admitted to a public hospital in Turkey with the diagnosis of COVID-19. In the study, age, unit of hospitalization, gender, the average hospitalization time, chronic disease and invoice amounts were evaluated. The average invoice amount for each patient was calculated as \$653.03. The average length of stay is 5.38 days and the average daily invoice amount per person is \$121.37. Independent variables of age, hospitalization unit (service, intensive care unit), chronic disease (yes, no) and average hospitalization time (day) accounted for $79.3 \%$ of the change in the cost of treatment for COVID19. As a result, it can be said that the cost of treatment for COVID-19 is quite high, the costs of treatment will increase depending on the number of patients receiving treatment for COVID-19, and it can be a significant financial burden on SSI.
\end{abstract}

Keywords: COVID-19, treatment costs, social security institution, Turkey

\section{Öz}

Bu çalışmanın amacı COVID-19 tanısıyla hastaneye yatan hastaların tedavi maliyetlerinin Sosyal Güvenlik Kurumuna (SGK) yükünü ve COVID-19 tedavi maliyetlerinin belirleyicilerini araştırmaktır. Araştırma retrospektif tipte bir araştırmadır. Araştırmada, Türkiye'de bir kamu hastanesine COVID-19 tanısıyla yatışı yapılan 389 hasta dosyası incelenmiştir. Araştırmada hastaların yaş, yatış yapılan birim, cinsiyet, ortalama yatış süresi, kronik hastalık ve fatura tutarları değerlendirilmiştir. Her bir hasta için ortalama fatura tutarı \$653,03 olarak hesaplanmıştır. Ortalama yatış süresi 5,38 gündür ve kişi başı günlük ortalama fatura \$121,37'dır. Bağımsız değişkenler olarak belirlenen yaş, yatış yapılan birim (servis, yoğun bakım), kronik hastalık (var, yok) ve ortalama yatış süresi (gün) değişsenlerinin bă̆ımsız değişken olan COVID19 tedavi maliyetindeki değişimin \%79,3 'ünü açıkladığı görülmüştür. Sonuç olarak, COVID-19'un tedavi maliyetlerinin oldukça yüksek olduğu, COVID-19 nedeniyle tedavi gören hasta sayısına bağll olarak tedavi maliyetlerinin yükselebileceği ve SGK'ya önemli bir mali yük olabileceği söylenebilir.

Anahtar Kelimeler: Covid-19, tedavi maliyetleri, sosyal güvenlik kurumu, Türkiye 


\section{INTRODUCTION}

On December 8, 2019, the first case of pneumonia was detected near a seafood market in Wuhan, the capital of Hubei province, in China. Until the end of December 2019, a group of patients had cases with similar signs of pneumonia. This disease was found to be caused by a new coronavirus, and this new coronavirus was named SARS-CoV-2. Later, the World Health Organization (WHO) named this disease as COVID-19 (Qiu et al. 2020: 1128; Kooraki et al. 2020: 447; Lake, 2020: 124; Guo et al. 2020: 2). The disease spread all over the world in a short time after its emergence (Lai et al., 2020: 1). On March 11, 2020, WHO officially declared the coronavirus (COVID-19) outbreak to be a global pandemic (Di Gennaro et al. 2020: 1).

The number of people who got the disease in the period between 09.10 .2020 since the first case was seen, reached $36,237,403$. The number of people who died due to COVID-19 is $1,054,868$. The country with the highest loss of life is the United States of America. It is followed by India and Brazil, respectively (World Health Organization [WHO], 2020). In Turkey, the first case was detected on 11 March 2020 ("Sağlık Bakanı Koca: Türkiye", 2020). As of 08.10.2020, the number of people infected with COVID-19 disease in Turkey was 330,753. The number of people who died is 8,667 (Republic of Turkey Ministry of Health, 2020). The COVID-19 pandemic has had significant health consequences as well as significant economic impacts.

The COVID-19 pandemic has also triggered fears of an impending economic crisis and recession. Since many countries have adopted strict quarantine policies, economic activities have been severely limited. Social distancing, self-isolation, and travel restrictions have resulted in a decrease in the workforce and the loss of many jobs in all economic sectors. The need for medical resources has increased significantly. The food sector also faced increasing demand due to panic buying and stockpiling of food products (Nicola et al. 2020: 185; Zhang et al. 2020:1).

The economic impacts caused by the COVID-19 pandemic have produced results similar to those of large-scale, extreme, natural disasters (Bonaccorsi et al. 2020:15530). In 2003, severe acute respiratory syndrome (SARS) was estimated to cost the world between US \$ 30-100 billion. While SARS was mainly in China, the COVID-19 outbreak has already turned into a worldwide crisis and acts as a "once-in-a-century pathogen." Therefore, a much greater impact on the global economy is expected (Zhang et al. 2020: 1). The impact of the economic crisis caused by the pandemic on individual households is difficult to predict due to the uncertainty of the length of the crisis, for example, the long duration of "staying at home", as well as the many uncertainties surrounding the affected industries. According to a report prepared by the World Bank, it is predicted that 11 million people will be affected by poverty in East Asia and the Pacific. The US economy, where the gross domestic product (GDP) fell by $4.8 \%$ in the first quarter, is expected to enter a recession with a $5.0 \%$ contraction in 2020 in a possible scenario. It is estimated that there will be $7.25 \%$ economic contraction in the European Union countries. Southeast Asian countries such as Indonesia, Malaysia, Philippines, Thailand and Vietnam are also facing economic difficulties due to the decrease in trade and tourism (Martin et al. 2020: 2).

The COVID-19 epidemic had a significant impact on the health sector along with its effects on the overall economy. The pandemic has challenged healthcare organizations on many fronts, including training healthcare professionals on new protocols, supplying protective equipment and ventilators, and creating additional intensive care units and COVID-19 patient beds. Without government assistance, the financial burden on hospitals that threatened survival increased further. Hospitals had to reduce other healthcare activities other than COVID-19 cases. Due to the restrictions, patients also delayed receiving many health services other than emergency services. In the US, it is estimated that there is a $12 \%$ reduction in hospital income due to reductions in surgical procedures. Hospital profit margins cannot overcome these losses. This will cause financial constraints for hospitals and surgeons, leading to budget cuts and employee leave. Given the size of the healthcare 
sector, this contraction would greatly contribute to increasing unemployment and stagnation in the overall national economy (Anoushiravani et al. 2020: 937).

COVID-19 can lead to unprecedented changes in both healthcare spending and GDP. The first step in predicting how COVID-19 might affect the health share of GDP is to predict how COVID-19 will affect health expenditures (Glied and Levy, 2020). Turkey, General Health Insurance, the scope of social security is all related to that particular regardless of all individuals, including immigrants who live in the country COVID-19 diagnosis, treatment and follow-up services, provides free, including intensive care treatment. The decrease in tax or premium resources to be used in the financing of health systems will deeply affect the financing of insurance systems. It can be stated that one of the areas where post-pandemic health systems will have the most difficulties will be financing. Both the decrease in employment and the level of wages, the decline in public revenues and the absence of the same decrease in health expenditures will constitute the main reasons for the financial problem (İşlek et al. 2020).

One of the biggest concerns with the COVID-19 pandemic is the direct medical cost and resource use burden imposed on the healthcare system. A simulation model has been developed to represent the US population and what can happen to each person infected. According to this model, a single symptomatic COVID-19 case alone could result in $\$ 3,045$ direct medical costs during the course of the infection. If 80 percent of the US population becomes infected, the result is an average of 44.6 million hospitalizations, 10.7 million intensive care unit admissions, 6.5 million patients needing a ventilator, 249.5 million hospitalization days, and \$ 654 billion direct medical costs may occur. If 20 percent of the U.S. population becomes infected, an average of 11.2 million hospitalizations, 2.7 million intensive care unit admissions, 1.6 million patients needing a ventilator, 62.3 million hospitalization days and $\$ 163.4$ billion direct medical costs may occur (Bartsch et al. 2020: 2).

Accordingly, it can be said that the cost of COVID-19 treatment is high and depending on the number of cases, it can affect the hospital and the economy of the country. Therefore, it is important to know the cost of treatment for each patient with COVID-19 and to calculate the burden on SSI. The concept of social security is defined as a system that meets the subsistence and living needs of people whose income or earnings are interrupted due to an occupational or social risk, without the need for the help of others. According to the International Labor Organization (ILO), "the protection provided by the society to its members by a number of public measures against economic and social difficulties caused by the total or substantial loss of earnings arising from illness, pregnancy, occupational accident, unemployment, old age and death, providing care and supporting families with children". Social security affairs are carried out by SSI in Turkey. This institution makes reimbursement to health institutions for the treatment services that its members receive from hospitals (SSI, 2020). To our knowledge, there is no study that determining the cost of COVID-19 treatment in Turkey. This study aims to determine the burden of treatment costs on SSI of hospitalized patients diagnosed with COVID-19 and to reveal the determinants of treatment costs.

\section{MATERIALS AND METHODS}

The research is a retrospective study. This study examined the files of the patients that were admitted to a public hospital in Turkey with the diagnosis of COVID-19, discharged in June 2020 and completed invoicing procedures. A total of 389 patient files were included in the study. The currency used in hospital invoices was Turkish Lira (TL). Patient invoices amounts were converted from TL to the United States Dollar (USD). 1 USD was accepted to be equal to 6.85 TL by the date of June 30, 2020 (Central Bank of the Republic of Turkey, 2020). The cost of COVID-19 was then computed in USD. 
The invoice amounts calculated for each patient to be sent to SSI, length of stay, gender, age, hospitalization unit and chronic disease status were obtained from the patient files and transferred to the Statistical Package for the Social Sciences (SPSS 21) software. Descriptive findings related to the specified variables were evaluated with descriptive statistics such as mean, percentage and frequency. The significance test (t-test) of the difference between the two averages was used to test whether the invoice amount differed according to the length of stay, gender, age, hospitalization unit and chronic disease status. In the research, it was also investigated whether the average length of hospitalization differs according to age, gender, test result, chronic disease status and hospitalization unit variables. The t-test was used for this. The variable of COVID-19 treatment cost was considered as dependent variable, whereas, the variables of age, hospitalization unit (service, intensive care unit), chronic disease (yes, no) and average hospitalization time (days) were considered as independent variables. The effect of independent variables on the dependent variable was tested by regression analysis. The hospital where the study was conducted is a second-level health institution with general hospital status, declared as a pandemic hospital by the Ministry of Health. In order to conduct this research, the ethical approval was obtained from the Ministry of Health (date and number: 19.05.2020/T14-4238) and an additional ethical approval was obtained from Batman Regional State Hospital Ethics Committee (date and number: 20.07.2020 / 2667). In addition, administrative permission was obtained from the hospital where the study was conducted (date and number: 04.08.2020 / 2808).

\section{RESULTS}

The number of patients who were hospitalized with the diagnosis of COVID-19 in the hospital where the study was conducted and whose discharge procedures were completed in June is 389 . It has been stated that in individuals over 65 years of age, COVID-19 progresses more severely and causes more deaths (Üstün and Özçiftçi, 2020). In addition, the patients included in the study are 18 years and older. For this reason, the patients considered in the study were evaluated by dividing them into two groups as those over 65 years of age and those between 18-65 years. Approximately three-quarters of the patients were 65 years or younger.

Slightly more than half of them were male (51.7\%). Approximately one in five patients had a chronic disease. While the rate of those who treated in the ward was $88.2 \%$, the rate of those who treated in the intensive care unit was $11.8 \%$ (Table 1).

Table 1: Descriptive Findings $(\mathrm{N}=389)$

\begin{tabular}{llcl}
\hline Variables & Group & $\mathbf{N}$ & $\mathbf{\%}$ \\
\hline \multirow{2}{*}{ Age } & $18-65$ & 286 & 73.5 \\
& Over 65 & 103 & 26.5 \\
\hline \multirow{2}{*}{ Gender } & Female & 188 & 48.3 \\
& Male & 201 & 51.7 \\
\hline \multirow{2}{*}{ Hospitalized Unit } & Service & 343 & 88.2 \\
& Intensive care unit & 46 & 11.8 \\
\hline \multirow{2}{*}{ Chronic Disease } & No & 312 & 80.2 \\
& Yes & 77 & 19.8 \\
\hline
\end{tabular}

The average length of stay and the average invoice amount per person of the patients included in this study were provided in Table 2 . The average daily amount of the invoice for each patient was obtained by dividing the average invoice amount per person into the average length of stay. The average invoice amount for each patient was $\$ 653.03$. The average length of stay was 5.38 days and the average daily invoice amount per person was $\$ 121.37$. The invoices of patients over 65 years of age, with chronic diseases and treated in intensive care units were found to be higher. There is a 
significant difference between the invoice amounts of the patients treated in the intensive care unit and the patients treated in the ward. The average invoice amount for each patient followed in the ward was $\$ 518.41$, whereas, the average invoice amount of the patients treated in the intensive care unit was $\$ 1656.78$.

Table 2: Findings Regarding Invoice Amounts

\begin{tabular}{|c|c|c|c|c|c|}
\hline Variables & Group & $\mathbf{N}$ & $\begin{array}{c}\text { Average } \\
\text { Invoice } \\
\text { Amount Per } \\
\text { Person (\$) }\end{array}$ & $\begin{array}{c}\text { Average } \\
\text { Hospitalization } \\
\text { Time } \\
\text { (Day) }\end{array}$ & $\begin{array}{c}\text { Daily Average } \\
\text { Invoice Amount } \\
\text { Per Person } \\
(\$)\end{array}$ \\
\hline \multirow{2}{*}{ Age } & $18-65$ & 286 & 588.26 & 5.12 & 114.89 \\
\hline & Over 65 & 103 & 832.88 & 6.07 & 137.21 \\
\hline \multirow{2}{*}{ Gender } & Female & 188 & 720.42 & 5.59 & 128.88 \\
\hline & Male & 201 & 589.99 & 5.18 & 113.90 \\
\hline \multirow{2}{*}{ Hospitalized Unit } & Service & 343 & 518.41 & 4.91 & 105.58 \\
\hline & Intensive Care Unit & 46 & 1656.78 & 8.86 & 187.00 \\
\hline \multirow{2}{*}{ Chronic Diseases } & No & 312 & 607.83 & 5.21 & 116.66 \\
\hline & Yes & 77 & 836.17 & 6.03 & 138.67 \\
\hline General & & 389 & 653.03 & 5.38 & 121.37 \\
\hline
\end{tabular}

Table 3 showed the results of the t-test whether the invoice amounts show a statistically significant difference according to the age, gender, hospitalization unit and chronic disease variables. When Table 3 was examined, it was seen that there was a statistically significant difference between the invoice amounts according to age, hospitalization unit and chronic disease variables $(\mathrm{p}<0.05)$. There is no statistically significant difference between invoice amounts according to the variable of gender $(\mathrm{p}>0.05)$.

Table 3: Comparison of Invoice Amounts According to Variables (\$)

\begin{tabular}{|c|c|c|c|c|c|c|}
\hline Variables & Group & Number & Mean & SD $^{\mathbf{a}}$ & $\mathbf{t}$ & $\mathbf{p}$ \\
\hline \multirow{2}{*}{ Age } & $18-65$ & 286 & 588.26 & 546.39 & \multirow{2}{*}{-2.448} & \multirow{2}{*}{0.016} \\
\hline & Over 65 & 103 & 832.88 & 959.69 & & \\
\hline \multirow{2}{*}{ Gender } & Female & 188 & 720.42 & 750.87 & \multirow{2}{*}{1.863} & \multirow{2}{*}{0.063} \\
\hline & Male & 201 & 589.99 & 618.35 & & \\
\hline \multirow{2}{*}{ Hospitalized Unit } & Service & 343 & 518.41 & 361.35 & \multirow{2}{*}{-5.549} & \multirow{2}{*}{0.000} \\
\hline & Intensive Care Unit & 46 & 1656.78 & 1385.14 & & \\
\hline \multirow{2}{*}{ Chronic Disease } & No & 312 & 607.83 & 635.97 & \multirow{2}{*}{-2.216} & \multirow{2}{*}{0.029} \\
\hline & Yes & 77 & 836.17 & 847.22 & & \\
\hline
\end{tabular}

a: Standard Deviation

Table 4 showed the distribution and comparison of the average length of stay according to age, gender, test result, hospitalization unit and chronic disease variables. The average length of stay is higher in patients over 65 years of age, women and patients hospitalized in the intensive care unit. While there was no statistically significant difference between the duration of hospitalization according to gender and chronic disease variables ( $>0.05)$, a statistically significant difference was found between the length of hospitalization, age and hospitalization unit variables $(p<0.05)$. 
Table 4: Comparison of Average Length of Stay by Variables

\begin{tabular}{|c|c|c|c|c|c|c|}
\hline Variables & Group & Number & Mean & SD $^{\mathbf{a}}$ & $\mathbf{t}$ & p \\
\hline \multirow{2}{*}{ Age } & $18-65$ & 286 & 5.12 & 3.10 & \multirow{2}{*}{-2.515} & \multirow{2}{*}{0.010} \\
\hline & Over 65 & 103 & 6.07 & 3.73 & & \\
\hline \multirow{2}{*}{ Gender } & Female & 188 & 5.59 & 3.21 & \multirow{2}{*}{1.213} & \multirow{2}{*}{0.220} \\
\hline & Male & 201 & 5.18 & 3.38 & & \\
\hline \multirow[b]{2}{*}{ Hospitalized Unit } & Service & 343 & 4.91 & 2.49 & \multirow[b]{2}{*}{-8.264} & \multirow[b]{2}{*}{0.000} \\
\hline & $\begin{array}{l}\text { Intensive Care } \\
\text { Unit }\end{array}$ & 46 & 8.86 & 5.72 & & \\
\hline \multirow{2}{*}{ Chronic Disease } & No & 312 & 5.21 & 3.15 & \multirow{2}{*}{-1.96} & \multirow{2}{*}{0.051} \\
\hline & Yes & 77 & 6.03 & 3.78 & & \\
\hline
\end{tabular}

a. Standard Deviation

Table 5: The Impact of Age, Hospitalization Unit, Chronic Disease and Average Hospitalization Time Variables on COVID -9 Treatment Cost

\begin{tabular}{|c|c|c|c|c|c|c|}
\hline Variables & B & SD & $\beta$ & $\mathbf{T}$ & $\mathbf{p}$ & VIF \\
\hline Fixed & -752.867 & 66.862 & & -11.260 & .000 & \\
\hline Age & -32.416 & 40.127 & -.021 & -.808 & .420 & 1.233 \\
\hline Hospitalized Unit & 524.096 & 57.563 & .246 & 9.105 & .000 & 1.359 \\
\hline Chronic Disease & -17.005 & 43.784 & -.010 & -.388 & .698 & 1.197 \\
\hline $\begin{array}{l}\text { Average Hospitalization } \\
\text { Time }\end{array}$ & 160.616 & 5.244 & .771 & 30.631 & .000 & 1.177 \\
\hline
\end{tabular}

The results of multiple regression analysis to determine the factors affecting the cost of COVID19 are presented in Table 5. Variance Inflation Factor (VIF) coefficients of less than 5 show that there is no multiple connectivity problem. The VIF values in this study vary between 1.178 and 1.196 . The established regression model was found to be statistically significant $(\mathrm{F}=367.945 ; \mathrm{p}<0.001)$. Independent variables of age, hospitalization unit (service, intensive care unit), chronic disease (yes, no) and average hospitalization time (day) accounted for $79.3 \%$ of the change in the cost of treatment for COVID-19. According to the standardized regression coefficient ( $\beta$ ), the order of importance of independent variables on COVID-19 treatment cost is as follows: the average hospitalization time, hospitalization unit, age and chronic disease. When the t-test results on the significance of regression coefficients were examined, it was observed that the average hospitalization time and the hospitalized unit variables had a significant effect on the cost of COVID-19 $(p<0.05)$, while age and chronic disease variables did not have a significant impact on the cost of COVID-19 treatment $(p>0.05)$.

\section{DISCUSSION}

In this study, which examined the invoice of 389 patients hospitalized with the diagnosis of COVID19 sent to SSI for reimbursement, the average invoice amount per person was $\$ 653.03$. The average length of stay of the patients was calculated as 5.38 days and the average daily invoice amount per person was $\$ 121.37$. Independent variables of age, hospitalization unit (service, intensive care unit), chronic disease (yes, no) and average hospitalization time (day) accounted for $79.3 \%$ of the change in the cost of treatment for COVID-19. It is clear that the epidemic has important economic effects as well as health consequences. It can be said that the treatment costs of those infected with this disease constitute an important economic burden. Bartsch et al.'s study (2020: 2) found that a 
symptomatic COVID-19 case would have a direct medical cost of \$3.045 in the USA. Only the amount of spending done for one patient may seem small. However. the feature of the epidemics is that they affect a large number of people in very large geographies. In a report published by the British Newspaper The Guardian in the UK based on the document prepared by the British Public Health (PHE). it was stated that 4 out of 5 people are expected to be infected. and the epidemic could continue until the spring of 2021 (The Guardian. 2020). Some experts reported on some visual media channels in Turkey say that up to $80 \%$ of the society will have COVID-19 disease. It cannot be said that all COVID-19 cases show symptoms and require hospitalization. Nishiura et al. (2020: 154) conducted a study which consisted of 565 people and found that $30.8 \%$ of the cases did not show symptoms. In a study by Lazzerini and Putoto (2020: 641). it was stated that $39.8 \%$ of a total of 27.980 COVID-19 cases were hospitalized and $6.6 \%$ were hospitalized in the intensive care unit.

According to Turkish Statistical Institute (TSI). Turkey's population is 83 million 154 thousand 997, in 2019 (TSI, 2020). When considering of $80 \%$ of the population of Turkey could be infected with COVID-19 and $30 \%$ of these cases will require hospitalization, it can be predicted that the cost of those to the SSI would be approximately $\$ 13$ billion. Considering this amount, it can be said that COVID-19 will cause a substantial economic burden.

When calculating the cost of treatment of a disease, both direct medical costs and indirect costs need to be taken into account. Direct costs: Expenditures made by individuals, insurance companies or the state for the care, treatment and protection of a disease that occur directly as a result of a disease. Indirect costs mean the loss of productivity in economies as a result of illness and are social costs caused by illness, disability or premature death (Beyhun and Çilingiroğlu, 2004: 388; Sandalcı and Tuncer, 2020: 29). In this study, only the expenditures made by the SSI for COVID-19 patients were evaluated. Out-of-pocket payments made by the patients and their relatives and indirect costs were excluded. It can be said that COVID-19 will create a much higher cost burden when other direct costs and indirect costs such as out-of-pocket payments made by the patients and their relatives are taken into account.

In the study, it was observed that the hospitalized unit variable was the factor that had the most impact on COVID-19 treatment costs after the variable of average hospitalization time. The average invoice amount of patients admitted to an intensive care unit was found to be higher. The average invoice amount of those admitted to the intensive care unit is more than three times the average invoice amount of the patients followed up in the ward. Higher technology is used in intensive care units. In addition, since the condition of the patients in the intensive care unit is more severe, more tests are performed and more treatment is applied to these patients. Therefore, the cost of hospitalization in intensive care units is higher.

This research study has some limitations. There are some patients who diagnosed with COVID19 and are treated at home. This research was conducted on patients who were hospitalization in a public hospital. Also, the data is limited to information in patient files.

\section{CONCLUSION}

COVID-19 spread all over the world in a short time after its emergence and had significant economic effects as well as health consequences. In this study, the invoices sent to the SSI for reimbursement of patients hospitalized with a diagnosis of COVID-19 disease were examined and it was found that COVID-19 constituted a significant cost burden. Due to the significant financial burdens of epidemics on insurance institutions, it can be useful for insurance institutions to take precautions regarding epidemics and allocate budget for this before outbreaks occur. It is known that preventive services cost less than curative services. Therefore, it is important to try to prevent the spread of the disease to more people in terms of both public health and costs. In the study, costs related to COVID-19 treatment were evaluated only based on the invoices sent to the SSI. In order to expand the scope of 
the research, it is recommended to conduct studies that include out-of-pocket payments and indirect costs (time, loss of workforce, etc.) and include larger patient groups.

\section{REFERENCES}

Anoushiravani, A.A., O'Connor, C.M., DiCaprio, M.R. and Iorio, R. (2020). Economic impacts of the COVID-19 crisis: An orthopaedic perspective. The Journal of Bone and Joint Surgery, (102), 937-41

Bartsch, S.M., Ferguson, M.C., McKinnell, J.A., O'Shea, K.J., Wedlock, P.T., Siegmund, S.S. and Lee, B.Y. (2020). The potential health care costs and resource use associated with COVID-19 in the United States: A simulation estimate of the direct medical costs and health care resource use associated with COVID-19 infections in the United States. Health Affairs, https://doi.org/10.1377/hlthaff.2020.00426

Beyhun, N.E. and Çilingiroğlu, N. (2004). Hastalık maliyeti ve astım. Tüberküloz ve Toraks Dergisi, 52(4), 386-392

Bonaccorsi, G., Pierri, F., Cinelli, M., Flori, A., Galeazzi, A., Porcelli, F., ... and Pammolli, F. (2020). Economic and social consequences of human mobility restrictions under COVID-19. Proceedings of the National Academy of Sciences, 117(27), 15530-15535

Central Bank of the Republic of Turkey (2020, 13 Ekim). Gösterge Niteliğindeki Merkez Bankas1 Kurlar1. https://www.tcmb.gov.tr/kurlar/kurlar_tr.html

Di Gennaro, F., Pizzol, D., Marotta, C., Antunes, M., Racalbuto, V., Veronese, N. and Smith, L. (2020). Coronavirus diseases (COVID-19) current status and future perspectives: A narrative review. International Journal of Environmental Research and Public Health, 17(8), 2690. doi: 10.3390 / ijerph 17082690

Sağlık Bakanı Koca: Türkiye'de ilk koronavirüs (Covid-19) vakası tespit edildi. (2020, 15 Nisan). Euronews. https://tr.euronews.com/2020/03/10/sagl-k-bakan-koca-koronavirus-covid-19-salgn-ile-ilgili-ac-klama-yap-yor

Glied, S. and Levy, H. (2020). The potential effects of coronavirus on national health expenditures. Jama, 323(20), 2001-2002

Guo, Y.R., Cao, Q.D., Hong, Z.S., Tan, Y.Y., Chen, S.D., Jin, H.J., ... and Yan, Y. (2020). The origin, transmission and clinical therapies on coronavirus disease 2019 (COVID-19) outbreak - an update on the status. Military Medical Research, 7(1), 1-10

İşlek, E., Özatkan, Y., Bilir, M.K., Arı, H.O., Çelik, H. and Yıldırım, H.H. (2020). COVID-19 Pandemi yönetiminde Türkiye örneği: Sağllk politikası uygulamaları ve stratejileri. TÜSPE Yayınları

Kooraki, S., Hosseiny, M., Myers, L. and Gholamrezanezhad, A. (2020). Coronavirus (COVID-19) outbreak: What the department of radiology should know. Journal of The American College of Radiology, (7) 447-451

Lai, C.C., Shih, T.P., Ko, W.C., Tang, H.J. and Hsueh, P.R. (2020). Severe acute respiratory syndrome coronavirus 2 (sars-cov-2) and coronavirus disease-2019 (COVID-19): The Epidemic and the Challenges. International Journal of Antimicrobial Agents, 55(3) 1-9

Lake, M.A. (2020). What we know so far: COVID-19 current clinical knowledge and research. Clinical Medicine, 20(2): 124-127

Lazzerini, M. and Putoto, G. (2020). COVID-19 in Italy: Momentous decisions and many uncertainties. The Lancet Global Health, 8(5), e641-e642

Martin, A., Markhvida, M., Hallegatte, S., and Walsh, B. (2020). Socio-economic impacts of COVID19 on household consumption and poverty. Economics of disasters and climate change, 4(3), 453-479

Nicola, M., Alsafi, Z., Sohrabi, C., Kerwan, A., Al-Jabir, A., Iosifidis, C., ... and Agha, R. (2020). The socio-economic implications of the coronavirus pandemic (COVID-19): A review. International Journal of Surgery, 78, 185-193 
Nishiura, H., Kobayashi, T., Miyama, T., Suzuki, A., Jung, S.M., Hayashi, K., ... and Linton, N.M. (2020). Estimation of the asymptomatic ratio of novel coronavirus infections (COVID-19). International Journal of Infectious Diseases, 94, 154-155

Republic of Turkey Ministry of Health (2020, 9 Ekim). Genel Koronavirüs Tablosu. https://covid19.saglik.gov.tr/TR-66935/genel-koronavirus-tablosu.html

Sandalcı, U. and Tuncer, G. (2020). Obezitenin doğrudan ve dolaylı maliyetlerine ilişkin bir değerlendirme. Aksaray Üniversitesi İktisadi ve İdari Bilimler Fakültesi Dergisi, 12(2), 29-44.

Social Security Institution (SSI) (2020). Sosyal Güvenlik Kurumu Başkanlığı. (Accessed 13.10.2020), http://www.sgk.gov.tr/wps/portal/sgk/tr/kurumsal/kurumumuz

The Guardian (2020). Coronavirus outbreak. UK Coronavirus Crisis' to Last Until Spring 2021 and Could See 7.9m Hospitalised. (Accessed 05.10.2020), https://www.theguardian.com/world/ 2020/mar/15/uk-coronavirus-crisis-to-last-until-spring-2021-and-could-see-79m-hospitalised

Turkish Statistical Institute (TSI) (2020). Adrese Dayalı Nüfus Kayıt Sistemi. (Accessed 09.10.2020), https://www.tuik.gov.tr/tr/PreTablo.do/?alt_id=1059

Üstün, Ç. and Özçiftçi, S. (2020). COVID-19 Pandemisinin sosyal yaşam ve etik düzlem üzerine etkileri: Bir değerlendirme çalışması. Anadolu Kliniği Tıp Bilimleri Dergisi, 25(Special Issue on Covid-19), 142-153

Zhang, D., Hu, M. and Ji, Q. (2020). Financial markets under the global pandemic of Covid-19. Finance Research Letters, doi.org/10.1016/j.frl.2020.101528

Qiu, Y., Chen, X. and Shi, W. (2020). Impacts of social and economic factors on the transmission of coronavirus disease 2019 (COVID-19) in China. Journal of Population Economics, (33) 11271172

World Health Organization (2020, 9 Ekim). Coronavirus Disease (COVID-19) Dashboard. https://covid19.who.int/ 